\title{
Learning Basic Grammar Using Task-Based Learning: A Perspective on Analyzing Online Media Text
}

\author{
Dwi Astuti Wahyu Nurhayati \\ State Islamic Institute of Tulungagung, Indonesia \\ e-mail:dwiastuti@iain-tulungagung.ac.id
}

\begin{abstract}
:
This paper displayed the perspective on analyzing online media text using task-based learning in learning basic grammar. The data were collected for 6 months through observation, interview and questionnaires from July to December 2018 in IAIN Tulungagung. It involves 45 Indonesian undergraduate students who were taking English Basic Grammar with online media text. The data was analyzed using a descriptive qualitative approach. The finding revealed that the students got experience of using online media text as learning basic grammar medium. Their perspectives on analyzing online media text using task-based learning are various (not interesting, passive in the learning process, low interest in reading, tend to rely on friends, and difficult to analyze the online text). Furthermore, their' perspective of using task-based learning in learning Basic English Grammar can be categorized into five types: the act of acquring strategy, the experiencing process, the process of acquiring benefits, the pupils' responses, and evaluating their performance. It also reported that some benefits of task-based instruction strategy in teaching learning Basic English Grammar can be ability to deep understanding the materials, having good cooperation, having the ability to memorize, managing the time effectively, identifying the kinds of grammar part, and increasing the communication abilities. While the disadvantages of task-based learning in learning Basic English Grammar through analyzing the online media text included having difficulties in analyzing, not being used to with the learning model, getting bored and uncomfortable with the strategy, and being burdened with the task.
\end{abstract}

Keywords: online media text, perspective, task-based learning

\section{Introduction}

In the English Language, there are four basic language skills such as: speaking, listening, writing and reading. They are completed one each other. The communication in each language in the world has different roles. Public alertness on the emphasis of English as the essential channnel of conversation and connection in this global era has been increasing. In Indonesia, using and learning two or three languages among students and English lectureres, with English as foreign language (FL), Javanese as mother tongue (L1), and Indonesian as a second language or 
national language (L2) have received considerable attention. Commonly, the situation and background of English language learning and teaching (ELLT), and the goal of teaching English is to advance conversational appropriateness, that is, to gain consequential qualifucation and capability to correspond or get across in a diversity of communication situation (Nurhayati, et al., 2018). In English, speaking and writing is the major's thing that should be considered. In speaking there are some terms that must be available as vocabulary, pronunciation, and grammar. Vocabulary helps people in arranging the sentence to communicate and it can make the language more variety. While pronunciation is helped people to speak rightly based on the rule of English pronunciation. Grammar also gives a big influence in speaking because it is one of the terms that make the speaker and receiver understand what the mean. It is almost the same as writing. In here grammar is used as a writer to arrange the sentence correctly. Mastering grammar helps students to understand every word when they are reading, speaking, listening, and writing. Supposing that speaking and writing balanced it will build good communication among students. As long as grammar important thing in English, so the students should study hard to learn grammar. To learn grammar in the school or in the outside is better but usually, the students want to study seriously only in the school. It is the responsibility and challenges of the teacher to create an interesting learning form in the class. There are some difficulties of students when study grammar: First is the materials of grammar are complex so the students are difficult to memorize them properly. Next, the students assume that difficult to memorize 16 tenses because it is full of the pattern inside. They should understand one by one well to memorize. It also happens in the part of speech. Part of speech is the material that needs a patient and critical understanding to comprehend. The students should often read some text and understand which include noun, adjective, preposition, verb, adverb, or conjunction. Another difficulty is they hard to analyze phrases and clauses. The students confused to distinguish between phrase and clause because there are many types of them. The appropriate strategy taken by teachers is needed to make students comfortable and fun to study grammar in the class. In this study, the teachers use online media text to attract the students in learning grammar. In fact, English students department felt and got bored to read materials such as module, books, and they got lazy to do some tasks. It is different from online media which provide a lot of materials about grammar to help the students understand it easier. The other benefit when using online media is not only sophisticated but also can make the students enjoy learning and funning. As a result, the lecturer as researcher promotes learning basic grammar through analyzing online media text.

The effectiveness of task-based learning is much in demand by Asian peoples, especially in the traditional method. Actually, the authorities have taken the initiative to use a more communicative oral syllabus but there are obstacles such as class size, inadequate finance, and the time the teacher makes this learning problematic. In this study, researchers attempted to overcome this problem by reporting research actions on interactive assignments designed by teachers on a limited budget to be used in middle-class university classrooms in Japan. This describes how the task is used to facilitate interaction and use of a specific grammar form, English articles. (Thompson \& Millington, 2012). Choo \& Too, (2012) conducted the research which analyzed the teachers' perceptions in using task-based instruction (TBI) for the teaching of Grammar. His study talks about the connection of the theory to practice TBI and it explores teachers' perspective in using TBI in teaching grammar. The researchers being instructor it consists of 8 teachers from Chinese Private School. The first step is given a similar TBI lesson 
plan to conduct in their pre-intermediate classes, consist of Junior 1 and Junior 2 levels 13-14year-olds. The second is drawn up the lesson plan based on Willis Frame Work, (1996). It consists of a pre-test, task cycle, and language focus. The third is an analysis of the textbook to examine the grammar section. The analytical of this study focuses on the presentation and activity of the grammar section purposed by textbook writers. The result of this study is the teacher who taught that TBI held promise and indicated that they would be willing to incorporate TBI into their repertoire. TBI could be better than their usual approaches for teaching grammar. By the textbook, some researchers have the experience to adapt the course book materials would not much challenge to the teachers.

Meanwhile, a study conducted by Nathan (2012) describes the enriching the curriculum with task-based instruction. This article explained how TBI promotes language acquisition, reviews the literature pertaining to implementing TBI in the future routes for implementing TBI at the tertiary level in Japan. The ways incorporate this study are task-based units incorporated into course, a task supported or teaching using prior learning knowledge to practice and develop theory, task-based learning-task make up the foundation of the programs and project-based learning. The goals of the TBI approach to language teaching theoretically match the communicative demand for learning English as a foreign language or communication.

In addition, Yildiz \& Senel, (2017) handled a study which analyzes educating and directing sentence structure using language instruction which is based on task given to young. This study presents the effectiveness of task-based language on pupils' sentence structure ability in the course of directing sentence structure or syntax and linguistics. The student applied pre-test to examine their level to confirm the homogeneity between experimental and control groups. From pre-test, there is not a meaningful result; it was taken from the post-test to evaluate student progress between pre and post-test result. According to input, TBLT is further and extra adequate than conventional and classical accent, dialect, speech instruction design and approach in the course of educating sentence structure. There is a significant difference between TBLT and those who are not. In TBLT, the concern and apprehension height of the student is very inadequate, as it arised an anxiety or agony open setting and surroundings in a class. This research generates pupils acquire spirit, courage, tenacity, and certainty in the capacity, potential, and profieciency in English. Student captivating, compelling, and diverting school room climate, setting, surroundings set side by side the conventional approach compose the instruction further and higher competent or adequate than any several alternatives instruction design. Ultimately, there is no wonder essential or purposeful changeor contrast prominent of the empirical class or cluster. The result of TBLT is efficient and forceful in expandingmand rising sentence structure awareness of the pupis. TBLT should be a considerable alternative and be used in teaching sentence structure.

Jeon \& Hahn (2005) conducting research which is delving into foreign language educators' concept and recognition of Teaching Based Language Teaching in a fact or event investigation or survey of Asian Secondary school classroom practice. The method of this research is collecting data through questionnaires from 228 teachers at 38 different middle and high school in Korea. It analyzes used quantitative and qualitative. The first section is to gain info about teachers' teaching level, gender, and teaching experience. The second test is reviewing the practical understanding of TBLT. The third section is to know the teachers' position on TBLT classroom practice. The last is to rate the teacher reason for choosing or avoiding the 
implementation of TBLT. TBLT give a great impact on classroom practice. TBLT is considered as a practical control and facilities of student activities in class. Give that teachers lack practical application knowledge of task-based methods, the teacher should be given the opportunity to acquire knowledge about TBLT related to planning, implementing, and assessing.

Chiu (2011) conducted research which is described grammar teaching concept and practice in the task-based secondary English curriculum of Hongkong. This study aims to investigate how grammar teaching was perceived and practiced within the task-based secondary curriculum of Hongkong. The purpose of this study is to explore the transmission of curriculum ideas and examine whether the theory, policy, and practice align in the process of curriculum implementation. The method of this study examines through literature review and material analysis. Collected the data from lesson observation and interviews to investigate how grammar teaching was perceived and practiced. The result of this study shows that curriculum ideas often transfer fully to teaching materials or apply to practice or intended. There was evidence of interaction at different levels as participation in this curriculum implementation.

Douglas \& Kim (2015) conducted research which it seeks to examine the prevalence of taskbased language teaching in English academic perceptions and practice in the Canadian context. These are common examples of EAP tasks and the benefit and drawback of this approach for EAP students. This research used a qualitative method. The researchers were analyzing the data revealed that presentation, essay, interview. The result of this study is TBLT used by participants across Canada and is well accepted as a teaching approach. However, some concerns associated with task-based language teaching in English academic purposes. While Esfandiari, (2018) conducted research with present task-based learning applied in satisfactory Grammar coverage. This paper argues that there are enough opportunities for satisfactory grammar coverage throughout a task-based language teaching lesson.

While a study conducted by Kafipour et al (2018) who explained the effect of task-based language teaching on analytic writing in EFL classroom. This study attempts to investigate the effects of employing task-based language writing instruction on Iranian EFL learners' writing competence. This study used an experimental group and control group method. The experimental group performed writing tasks using TBLT techniques, while control group practiced writing skills using traditional writing exercises. The result shows significant improvement in the writing ability teaching techniques. Using task-based writing techniques improved The Iranian EFL learners' ability significantly in terms of a different aspect of the writing competence, including sentence mechanics, language use, vocabulary, and organization.

\section{Literature Review}

Task-based learning is a different way to teach languages. It can help students place themselves in situations such as in the real world, such as oral communication which functions to do certain tasks. TBL is language teaching approach that encourages learners to do things in the target language (Huang, 2016). A pedagogical task is a peach of classroom work that involves learners in comprehending, manipulating, producing or interacting in the target language while their attention is focused on mobilizing their grammatical knowledge in order to express meaning, and in which the intention is to convey meaning rather than manipulate form (Nunan, 2004). Task-based learning has benefits for students to benefit from using their skills at their current level. In TBL students must know many foreign languages and observe them. After that, they can 
hypothesize individually and finally be able to experiment. Task-Based Approach to Language allows needs analysis to be tailored to the needs of students identified supported by the findings of class-centered language learning research allow evaluation based on testing that refers to taskbased criteria allows for instructions that focus on form. There are some advantages of TBL such as: Can move the focus of the learning process from teacher to student, helping students to understand language as a tool, not as a specific goal, can bring teaching from abstract knowledge to real-world applications, tasks can help meet student needs and provide a framework for creating attractive classes.

TBL structural framework consists of three stages. The first is the pre-task. Pre-task can increase awareness introduction about the subject and assignments. This task used images, posters, and demonstrations. The function of the pre-task is to prepare the students to perform the task in a way that will promote acquisition (Ellis, 2006). The pre-task phase arrange the pupils during generating linguistically authentic definite and correct terms as long as it allows, donates and permits them the opportunities to analyze, examine, evaluate the later phases soon or presently (Yildiz \& Senel, 2017). In addition, pre-task draws up them to behave and complete effort or exercises in such manner that bolster and advertise procurement.

The second is task cycle which works and uses target language such as making a group working and pair work. Group work exercises can increase the importance of planning, reports, presentations. The task period phase is the phase in which pupils compete or seek to behave or achieve and complete the assignment accustomed to them in an synergism or harmony and reciprocal setting and situation. This phase adderesses and intends to evolve, expand and progress a situation, surroundings in which pupils seek to advance, enhance and upgrade their conversation intelligence (Yildiz \& Senel, 2017). Task cycle offers learners to use whatever language they already know to help improve their language under the teacher's guideline when reporting the task. There are three components of a task cycle as well as task, planning, and report.

Post Task according to Willis (2001, p. 178) as cited in Yildiz \& Senel (2017) as language focus. This task identifies and classifies common words and phrases. Practice languages and phrases in class. The post-task phase affords a number of options. These have three major pedagogic goals: to provide an opportunity for a repeat performance of the task, to encourage reflection on how the task was performed, and to encourage attention to form, in particular to those forms that proved problematic to the learners when they performed the task (Ellis, 2006). Post-task stage also provides an opportunity for students to reflect on their task and encourages attention to form, in particular to problematic forms which Education for the knowledge society. The posttask phase consists of two aspects; the facilitator must be the corrector and understand the reflections of students.

Grammar according to Greenbaum \& Nelson (2002) grammar is the whole system and structure of a language or of languages in general, usually taken as consisting of syntax and morphology (including inflections) and sometimes also phonology and semantics. So grammar is a structure used in the English language to arrange the sentence. There are some materials that explained in grammar such as tenses, part of speech, gerund, to-infinitive, etc. Online media is the new media that use modern way to share the information they are print media and electronic media. Online media need a computer-based tool and the connection to search and receive information. While online media text is the media that served in the text form such as an article, short story, e-book, 
etc. The advantages of using online media text are can make students more attractive to learn and fun. Besides that, the students are able to master digital media by doing this task.

\section{Research Methodology}

To produce learning media especially learning basic grammar using task-based learning, it is necessary to take a research and development approach. Research and development is a method for developing and testing a product. According to Sukmadinata (2003), as quoted in the fields of education, research and development can be used to develop books, modules, learning media, evaluation instruments, curriculum models, learning, evaluation, and others. According to him, in general, there are three steps of research and development, namely, 1) Preliminary studies by reviewing theories and observing existing products or activities, 2) Developing new product or activity programs, and 3) Testing or validating products or program activities that new.

This research has been conducted for one semester starting from July 2018 to December 2018. The place for research was in the IAIN Tulungagung campus. The people who are involved in learning activities and have relevant information about research themes are called informants. Informants in this research are taken from students of English programme in semester one. Total informants in this research as many as 45 Indonesian undergraduate students who were majoring in English, and took English Grammar course. Determination of these criteria is seen from the results of the post-observation questionnaire. The tools used for data collection are through the teaching process, observation, spread out questionnaire post observation and interviews using recording devices, and field notebooks.

The data in this study were in the form of research subjects, namely the population of the study as many as 45 English Language students. The informants in this study were also the same as the population. The number of informants will be based on the willingness of students to be interviewed. The use of interviews conducted online through recording devices is used by reason of strengthening virtual situations and direct interviews about understanding the material and the impressions obtained from the perspectives on analyzing online media text in the learning basic grammar using task-based learning. Questionnaires were conducted to obtain data about the opinions of informants regarding the learning grammar using task-based learning to conduct the perspective in analyzing online media text, while the dimensions of the research to be obtained through interviews were conducted to confirm the answers in the questionnaire including whether they were able to understand the material through the teaching-learning model and the form of difficulties faced by students. The shortcomings and strengths expressed by students also become one of the data sources that can increase the validity of student perceptions about education English sentence structure giving exercises positioned in training them to practice in analyzing phrases, clauses and sentences.

The research was conducted through a qualitative approach. Qualitative research is an approach to explore and understand the meaning of individuals or groups on a problem. Use of a qualitative approach by considering 2 (two) reasons. First, qualitative research is in accordance with the objectives of the research that has a deep understanding; this is reflected in the use of questionnaires, interviews, and observations in understanding data. Through interviews, the researcher can do further questions if the answers given have not been explored. Second, researchers want to get data in accordance with the settings or conditions of participants. Through observation, researchers can capture processes naturally without being covered. 
Primary data obtained through observation researchers can see the process naturally without being covered. Primary data is obtained through observation, questionnaires, and interviews with students through individual and group assessments. Participant observation was conducted to obtain information about how the understanding was obtained after participating in English Grammar learning through task-based learning. The research dimension to be obtained is the level of understanding of students regarding the teaching-learning model. In addition, a questionnaire was given to find out how participants' perspective of the advantages and disadvantages of analyzing online media text in English Grammar learning. In this case the present research aims to investiagte and explore the pupils' perspective of the benefits or the potency of the media of English teaching-learning in English Grammar course; while the interviews were conducted aimed at gaining a deep understanding of the focus of the research. Interviews are carried out virtually and directly. Virtual and face-to-face interviews between peer tutors are conducted to obtain accurate data. Virtual interviews are chosen with the aim of further strengthening the process in a virtual context. In other words, to answer the first problem formulation, the researcher used a questionnaire given during the post-observation which aimed to capture the perspective on analyzing online media text through giving task in English sentence structure learning.

In accordance with the qualitative research methodology, the analysis is inductive so it does not mean to prove the predictions of the researcher. All conclusions or theories that might be developed are formed from all data obtained in the field. The inductive analysis is carried out through activities: 1) analysis in the field together with data collection, 2) analysis in interactive forms and 3) analysis of the coding process. The interactive analysis model is a data analysis technique in qualitative research following an analysis model developed by several experts. The analysis is carried out through three components, namely: 1) data reduction, 2) data presentation, and 3) drawing conclusions and verification. This data analysis activity starts from data collection activities, then data analysis components, namely as follows: At the stage of data reduction, the process of selection, focusing, simplification, and abstraction of all types of information written on the field notes. This process takes place continuously along with data collection. Then the reduction is also carried out codification of data from the results of the analysis of observations and related interviews to facilitate further analysis.

The researcher used coding process with 6 component analyzes (Spradley, 2006; Creswell, 2009), namely (1) collecting raw text data (read text data, in this case, the questionnaires of preobservation and post-observation), (2) dividing and organizing information segments, (3) reading all data, providing segment codes or parts, and reduce the code or simplify the code which in this context all data taken from questionnaires, observation, and interview were analyzed based on their perspective as the participant in the implementation of online media text in learning grammar (4) change the code into themes into four dimensions or themes of research including students' perspective of task based learning by anaylize online media to Basic English Grammar also advantages and disadvantages of the implemented-strategy, (5) connect themes with theory and case studies, in this topic, the data were analyzed related to their understanding of theory of Basic English Grammar and delivering material by analysing online media text, (6) interpret or infer the meaning of the four research themes, cultural analysis which was related to students' way in learning influenced by their habit whether as passive or active learners in getting the knowledge, also their experiences in high school phase. 


\section{Finding}

To conduct this research through three steps, they are observation, interview, and questionnaire:

\subsection{The Observation's Result}

Based on observations, many students are lazy to do the assignments. About $60-70 \%$ of students are not interested in attending the class and do not have the motivation to learn, even more, they prefer focused on social media and joking with their friends. As many as $40 \%-60 \%$ of the students admitted that they tend to use an instant way of learning material and they prefer to browse all the materials using android or smartphone. They do not want to understand the materials on their own terms. They prefer to be passive and listen to the explanation from the teacher. Even when explained most of them did not pay attention and finally they asked their friends. From the observation results, around $80-90 \%$ of students have very low reading interest especially in reading online media text. This tendency resulted in them having difficulty receiving material because they did not get the initial knowledge. In fact, this initial knowledge is used to bring and make it easier for them to build an understanding of the next material. As many as $50-60 \%$ of the respondents confessed that they rely on friends in workmanship or understanding materials and they just trust, bank on and depend on their friends. and they also realized that they were just apathetic, dull, inattentive to read the references. Most of them adopt, choose, pick and go for the Korean Drama. As with the results of the above observations, this tendency occurs when they are lazy and do not understand the text chosen by themselves. The students asked their friends to help while the friends who are relied upon also have difficulties. $20-30 \%$ of students do not interest to analyze the online text because the media is not comfortable to use. Although this way is more practice the students prefer to use paper text. The students think that online text has more disablement.

\subsection{The Result of Interview}

\subsubsection{The Disadvantages of using Task-Based Learning to analyze online media text}

Based on the results of the interview, it was found that $70-80 \%$ of students at the beginning of Basic English Grammar learning felt difficult to analyze the online text. This is indeed natural because English Grammar has many concepts and types of material. So that to be able to master the material requires a deep understanding of the material.

From the interview results, 50\% most students felt shocked and not used to with the learning methods used by the lecturers because most of them when in high school were not taught by this method. With this method, the students are required to be more independently to get the text which they had to analyze. This is far different when they are still in middle school where the teacher gives the text to analyze simply way. All material has been provided by the teacher and students just learn the existing ones without having to look for other material sources.

The interview results showed that $20 \%$ of students taught using this method felt dislike and uncomfortable with the material being taught. In addition, they not only hate the subjects taught but also hate the lecturers who teach. As a result of this dislike, attitude students turn out to like to underestimate courses and related lecturers so that the ability to absorb material was also reduced.

As many as $70 \%$ of reposndents conceded that they have got burdened with the basic English grammar learning method and they also admitted that they are not used to studying and doing 
regular tasks. They find it difficult to manage or divide the time when doing Basic English Grammar assignments. Many of them were not willing to leave their busy lives. The students need a long time to read the online text because they used to delay the task.

\subsubsection{The Advantages of Using Task-Based Learning in Analyzing Online Media Text}

Based on the results of the interview, $80 \%$ of students felt happy because they found the practice method to learn English Basic Grammar by analyzing online text. the result showed $60 \%$ of students more criticism with task-based learning because they could classify the kinds of grammar types. The benefits obtained by students after experiencing the learning process in this method, the students have the ability to know their shortcomings and ways to overcome them.

$70 \%$ of students become more motivated by the existence of this learning method where they initially feel burdened eventually making it a big responsibility that must be completed on time. At first, they felt they were unable to complete this learning but after being passed it turned out that the pressure made them more advanced and the enthusiasm to complete the learning through the assignments given.

Lecturers provide consultations every week which facilitate and assist students in preparing material and self-readiness by reading the online text. With this, the lecturers could control the material were got from the online media and the lecturer could guide them in the right way. $70 \%$ of the respondents asserted and divulge that they assume, sense, consider and hold some fortune, advantages and opportunity by the existence of this consultation because they can be prepared, qualified, handy accessible, adjusted and more ripe in delivering the materials and it has been directed by the lecturer. In addition, a consultation can also build good relationships between lecturers and students.

\subsection{The Questionnaire's Result}

\subsubsection{The Learning Strategy Used by the Students in Task-Based Learning}

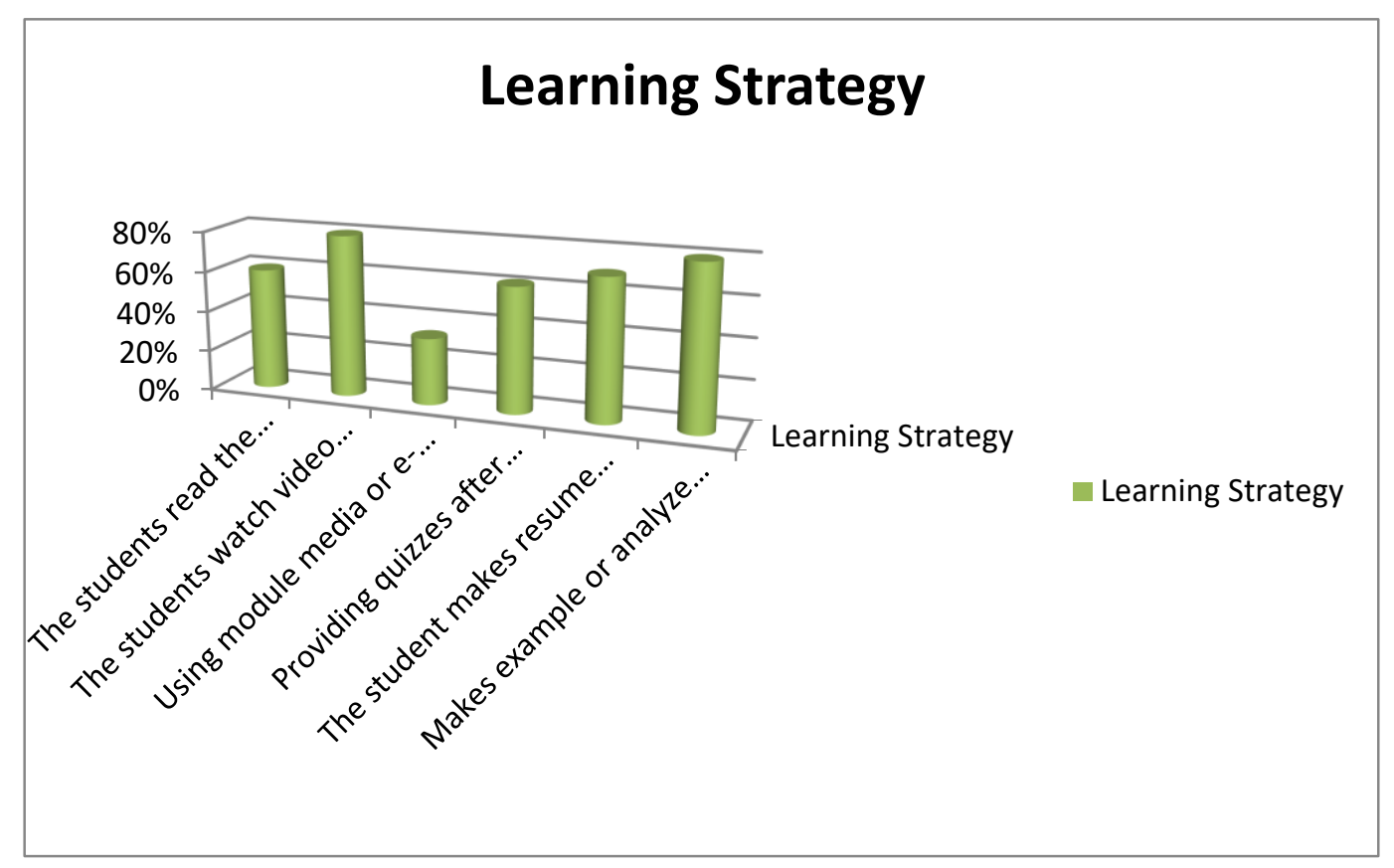

Figure 1. The Learning Strategy used by the Students in Task-Based Learning 
Proceeding from the figure above it could be claimed or dsclosed that the learning strategy which used by lecturer has some success method applied by students. There was some learning strategy used by the students in learning English basic grammar. $60 \%$ of the respondents conceded that they choose to read the books in order to learn the materials in hard copy or handbooks. This method can enhance student's skill because from reading books they can find kinds of grammar types. The students used YouTube as a media of watching the video (80\%), the video refers to English video by a native speaker, from the video students could know the right structure of grammar and pronunciation of the words. The students used module media or e-book (33\%) in learning grammar. From the e-book, they could found various types of text. The students provided quizzes (62\%) after explaining the materials; it was used to approve the student's understanding. The students make a resume (70\%) of the materials. The students made an example of the text and analyze it (80\%), so they could analyze the grammatically of English text or the structure of the sentences.

\subsubsection{The Learning Process using TBLT}

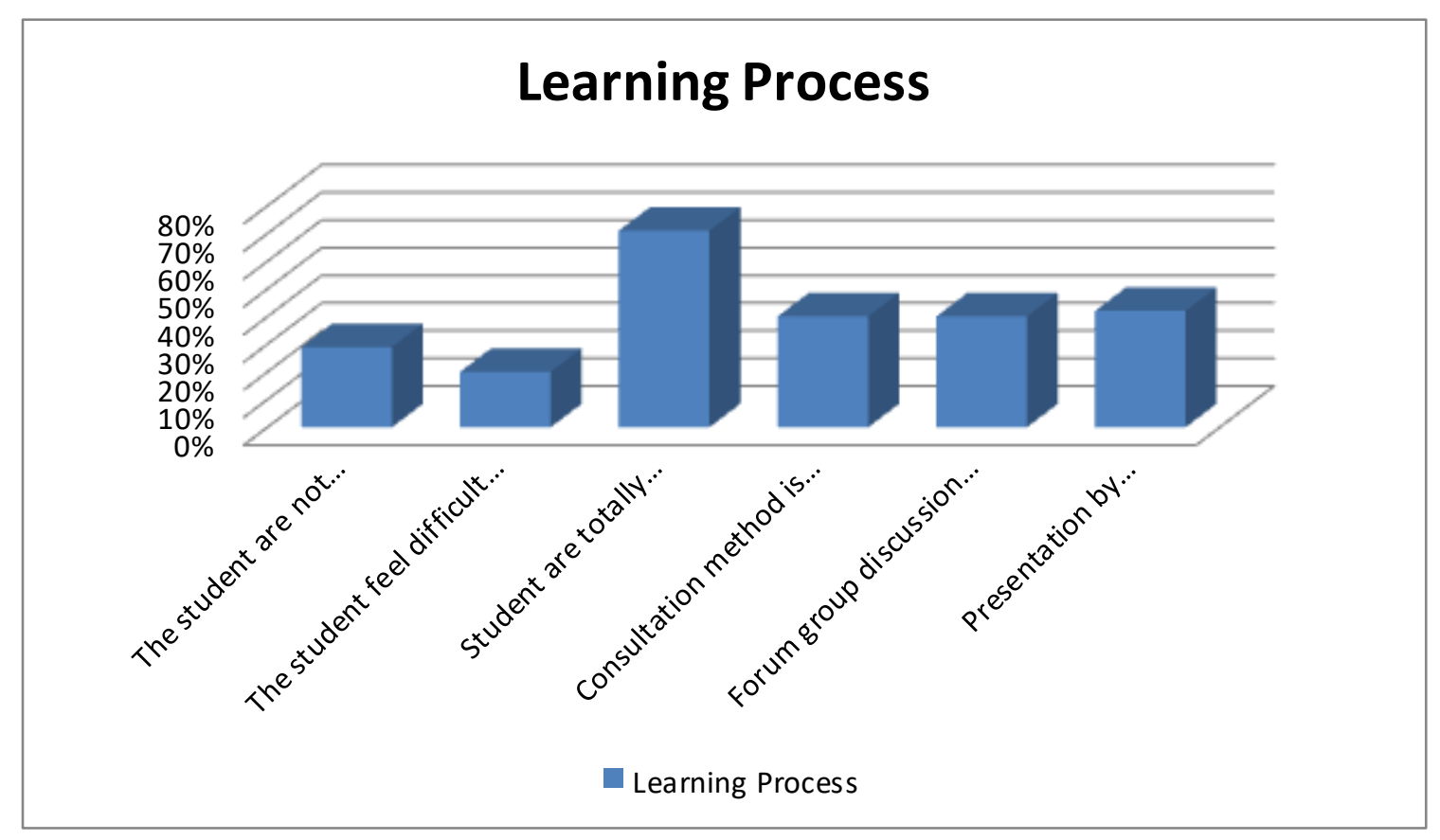

Figure 2. The Learning Process using TBLT

The task-based learning teaching method was not used by students (29\%) in English basic grammar learning. The students feel hard to understand the materials (20\%) of English basic grammar. The students are completely amazing (71\%) with the task-based learning teaching method because before they come to the university, their old teacher has not used this method or used traditional teaching method. In this English basic grammar course, the teacher held consultation method (40\%) and it runs effectively because it appraise the right understanding of the students and also the teacher can guide the students when they faced difficulties in their works. The forum discussion was run well or effectively (40\%) because the students can share their understanding of the materials also share the difficulties of the materials so they can help each other. The presentation includes the teaching technique run well (42\%) because by implemented task-based learning teaching method the students became a center so they must 
enhance their skill and extension their confidence when they deliver the materials of English basic grammar

\subsubsection{The Students'Responses}

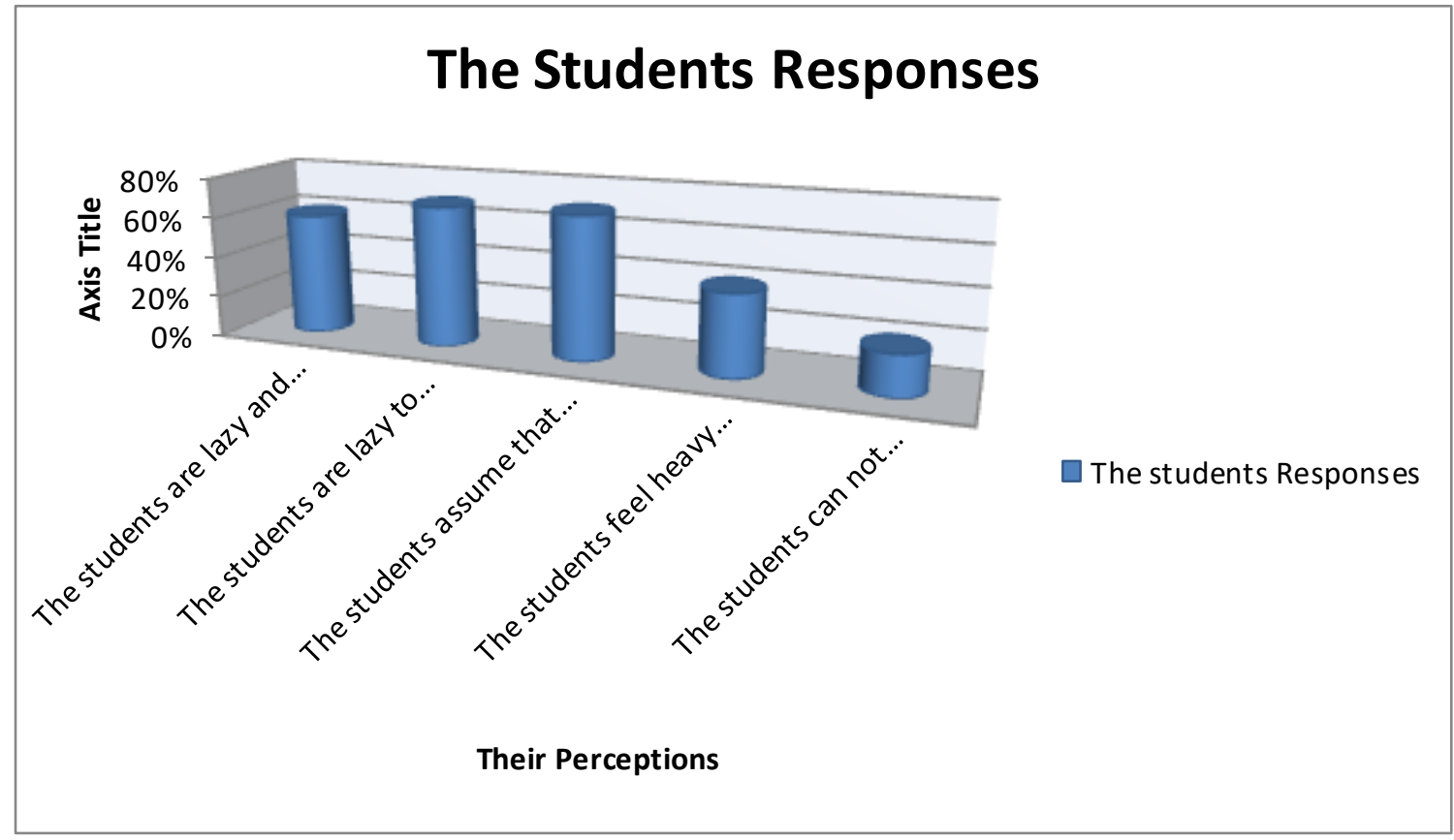

Figure 3: The Students Responses

The responses of the students using the task-based learning teaching method in learning English basic grammar appear some negative responses. The students are passive and careless (60\%) in the works. The students were lazy to come in class (69\%) when the English basic grammar course took place. The students expected (70\%) that English basic grammar was hard to understand. The students felt heavy, sturdy, and beefy with the task-based learning teaching method (40\%) because during this time they have not been using this learning method. The students cannot understand the English basic grammar materials well (20\%) with this task-based learning teaching method.

4.3.4 The Benefits of Task-Based Learning Teaching

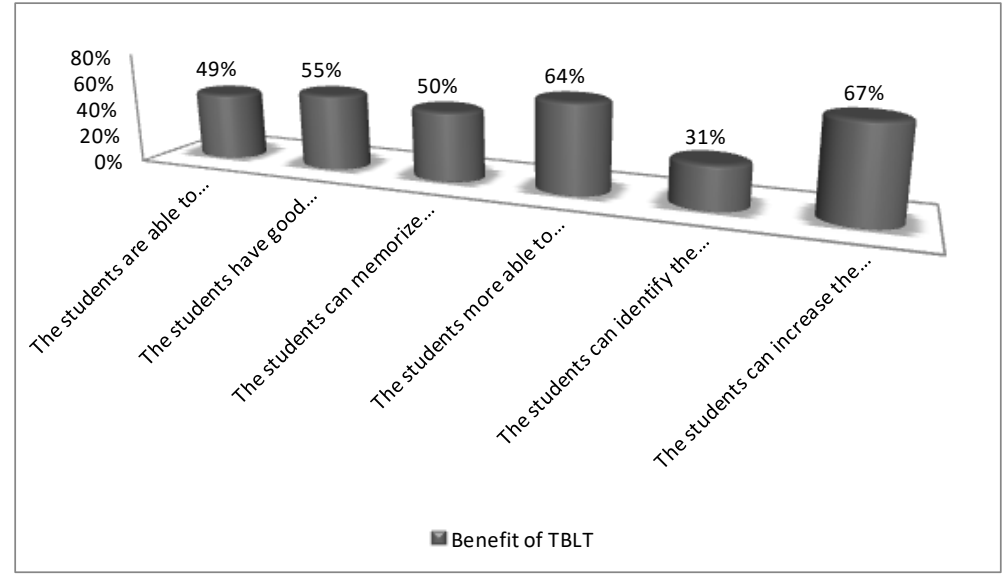

Figure 4. The Benefits of Task-Based Learning Teaching 
The advantages of using task-based learning teaching method based on the students perspective. The students have the ability to fix the understanding of the materials (49\%) that have been described from the group discussion or the other friends. The students have good cooperation (55\%) between teachers, group discussion or friends. The students have the ability to memorize the sentences, analyze (50\%) the online text on module media. The students are able to manage the time $(64 \%)$ to complete the target and submit it on time. The students are able to identify (31\%) the kinds of English Basic Grammar part. The communication ability of the students could increase (67\%) using the task-based learning method.

\subsubsection{Evaluating the Pair Up 's Performance}

The result of evaluating the student's performance showed that the students felt charity (40\%) for if provided a bad evaluation with their friends. Then the students felt a debt of gratitude to their friends (55\%) so as to give a positive evaluation. The students feel reluctant (4\%) if provide an evaluation that was negative but their friend has to pay the printout. The friend's relationship affects the assessment (46\%) of the students because they do not want their friends to get the bad value and uncomfortable if provide the bad evaluation.

\section{Discussion}

\subsection{The students' perspective on analyzing online media text seen from the observation}

Based on the result of the observation, firstly found that $80 \%$ of students have very low reading interest especially online media text than in the range $70 \%$ of students are not interested in attending the class and do not have the motivation to learn. Then, it discovered that students tend to rely on friends in completing the task in the range $50 \%$ and was supported that they only want the instant way in the range $40 \%$ where those do not want to understand the materials on their own terms. The lower range is $20 \%$, the students claimed that they were not interested in analyzing the online text because it is not comfortable.

Furthermore, this finding was also supported by the theory of reading habit more complete explanation stated by Muawanah, (2014) that several advantages of the reading habit. Those were as follows: (1) helping the mind performs effectively; ( 2 helping the students to develop some lexical items, (3) providing pattern or routine of reviewing texts loads creative eagerness and interest, (4) routine of reviewing texts means intellectual, mental and cognitive execise, (5) boots and encourages bookworms to acquire and admit a decisive and conclusive series of consciousness. So, the low interest in reading also affects students in learning Basic English Grammar should be increased. Reading needs to be developed to increase the students' ability in mastering Basic English Grammar, but some reasons cover it. Donald (2015) explained that "some factors influencing students' reading interest including students' motivation, uncontrolled sophisticated media such as phone \& computer, friends, and learning environment." The controlled environment, especially in learning class needs to be conducted to make the learning process run well. Although the attention of the environment is needed, it is also required the learning interest from each student. The motivation in learning particularly reading must be increased. It is also pararrel to Riswanto and Aryani, (2017) who found that the motivation of students in learning extends and maximize the student's achievement in learning. So, it is necessary for students to enhance and widen their motivation to get a better result and high achievement in learning especially Basic English Grammar. 


\subsection{The students' perception of the students on analyzing online media text based on the questionnaires.}

Due to the result of the questionnaires, it was divided into four themes: (1) The learning strategy, $60 \%$ of students read the books to learn. The students also used youtube as a media of watching the video to comprehend the materials in the range of $80 \%$. Besides the students using module media or e-book in range 33\% to learn grammar. From the e-book, they could found various types of text. $62 \%$ of the students providing quizzes after explaining the materials, it used to apprehend the understanding of students. The students made a resume of the materials in the range of $70 \%$. Moreover, in the range $80 \%$ the students make an example of the text and analyze it so they could analyze the grammatically of English text or the structure of the sentences. (2) In the learning process, the students' opinion was various. The first impression the students were not used by students in the range of $29 \%$, following by the students felt hard to understand the materials in the range of $20 \%$. In addition, the students are completely amazed by the range of $71 \%$. In this English basic grammar course, the teacher held a consultation method, there are $40 \%$ of students claimed that it is run effectively. The forum discussion is run well or effective in the range of $40 \%$. Then $42 \%$ of students said that the teaching technique was good and running well. (3) The responses of the students using the task-based learning teaching method in learning English basic grammar appear some negative responses. The students are passive and careless in the works in the range of $60 \%$. Next, the students are lazy to come to the class in the range of $69 \%$ when the English basic grammar course takes place. While in the range $70 \%$ the students expected that the English basic grammar is hard to understand. In addition, $40 \%$ of students feel heavy with the task-based instruction design. Moreover, 20\% of those students cannot understand the English basic grammar materials well. (4) The learning benefits through task-based learning teaching method based on students perspective, the students had the ability to fix the understanding of the materials in the range $49 \%$ followed by $55 \%$ of the students have a good cooperation. Therefore $50 \%$ of students had the ability to memorize the sentences, analyzed the online text on module media. Then in the range, $64 \%$ of the students are able to collect the task on time. While the pupils are capable of determining, classisfying and describing several kinds of English Basic Grammar part in the range of 31\%. The communication ability of the students is increased by using the task-based learning method in the range of $67 \%$. (5) The result of evaluating the student's performance there is $40 \%$ of the student's felt charity. Then in the range $55 \%$ the students feel a debt of gratitude to their friends. In range, $4 \%$ of the students feel reluctant their friend has to pay the printout. In addition, the friend's relationship affects the assessment of the students in the range of $46 \%$.

The experience was needed for a student to create the first knowledge about the learning material, method, or strategy that would be implemented. The fewer experiences made them require a big effort to come in the learning process. Nurhayati (2018) stated that "the experiences in learning help students to participate in the learning process". Thus, the experienced students who have ever study with task-based learning method are easy in order to run the assignmnet while some inexperienced students have to dig deeper to get the same level or position. Not only that, to get the best result of learning, the students' interest in learning must be created. However, some students are not as easy as the lecturer's willing due to their interest is on something that contains happiness. Kusmaryati and Amertaningrum (2017) on their research discovered that some strategies could be done to improve students' skills and willing in learning 
such as: playing games through handphone and watching movies which contain some amusement in it. Therefore, hopefully, lecturers have to be able to stimulate students or provide students interest more and improving their achievement in Basic English Grammar course. By mastering the Basic English Grammar, students could gain ability in English skills especially speaking and writing. Qosayere (2015) declared that grammar correction is effective on students writing skills and it is important to practice the grammar feedback and correction. Grammar also has a role in speaking as stated by Utaminingsih (2013) on her study "Grammar and vocabulary affected speaking, and the awareness of applying those two things helps students to practice speaking well." For that reason, it was necessary for students to extend and appraise their ability and mastering in Basic English Grammar course.

\subsection{The students' perspective on analyzing online media text based on an interview}

Based on the interview, it could be concluded that in learning Basic English Grammar through analyze online media text presents advantages and disadvantages that explained in various way by students. For the advantages, $80 \%$ of students felt happy after following the learning because of the new experience method to learn English Basic Grammar. In range, 70\% the students became motivated and the students also felt benefits by the existence of the consultation because they were ready and mastering the material and it can build a good relationship between the lecturer and students. Moreover, about $60 \%$ of students became critical to classify the kind of grammar types.

In addition, this finding is also supported by some researchers (Ellis, 2008; Hismanoglu, 2011) listed the advantages of task-based learning strategy to support foreign language learning those are: (1) TBLT contibutes and adminiters the opportunity for 'essential and instinctive' instruction inner the surroundings environment of school room, (2) It focuses on content or context beyond pattern; any how, this may also emphasize on instruction model, (3) It attempts pupils a productive and abundant data of foreign language (4) It is fundamentally driving and prompting, (5) It is persistent with a student-directed and concentrated on academic ideology but allows and donates admission, approval for educator absorotion, profit and advice, direction and supervision. (6) It supports to the advance, change, and developments of conversational eloquence during the time not disobey efficiency and truthfulness. (7) It can be expanded, disposed and displayed together along further more conventional design or methods. This is also in agreement with the results of Ganta's research (2015) that some weaknesses of task-based learning include: (1) task difficulty, (2) mismatch between the teachers' and learners' perceptions, (3) authenticity of task, (4) linguistics deficiencies, (5) outcome, (6) learners' needs neglected, (7) and diverse classes.

\section{Conclusion}

The issues of the research questions divulged that giving assignmnent and exercises in analysing sentence structure using online texts afford some benefits. first is the experienced students using online media text are very helpful for them in participating and learning English Basic Grammar with task-based learning. This is indicated by the opinion of all informants that more benefits are obtained by developing intensive technology-based using online media text; while the inexperienced students are willing to try harder to follow the class.

The second, many benefits obtained with English Basic Grammar using online media text which can attract students in learning such as the ability to deep understanding the materials, having 
good cooperation, having the ability to memorize, able to the time effectively, can identify the kinds of grammar part, and enhance the communication ability.

The third, the disadvantages of task-based learning in learning Basic English Grammar through analyzing the online media text such as the students still have difficulties in analyzing the online media text, the students are not used to implementing the learning model, they get bored and uncomfortable with the learning strategy, and being burdened with the task given.

\section{References}

Aryani, S. \& Riswanto, A. (2017). Learning Motivation and Students Achievement: Description Analysis and Relational Both. The International Journal of Counseling and Education, Vol. 2 (1), 42-47.

Chiu, Hazel Lai Wan. (2011). Grammar Concepts and Practice in the Task-Based Secondary English Curriculum of Hongkong.

Choo, J. P. L. \& Too, W. K. (2012). Teachers' Perceptions of using Task-Based Instruction (TBI) for the Teaching of Grammar. University of Nottingham, Malaysia Campus. Journal of Interdisciplinary Research in Education (JIRE) Vol. 2, Issue 1, 2012, pp. 47-64.

Creswell, J. W. (2009). Research Design: Qualitative, Quantitative, and Mixed Methods Approaches. Los Angeles: Sage Publication.

Donald, A.(2015). Students' Reading Interest: A Case Study at FKIP of The University of Pasir Pengairan. Journal of English Education, Vol. 1(1), 23-31.

Douglas, S., \& Kim, M. (2015). Task-Based Language Teaching and English for Academic Purposes: An Investigation into Instructor Perceptions and Practice in the Canadian Context. TESL Canada Journal, 31, 1. https://doi.org/10.18806/tesl.v31i0.1184

Ducker, Nathan. (2012). Enriching the Curriculum with Task-Based Instruction. Polyglossia Volume 22.

Ellis, Rod. (2006). The Methodology of Task-Based Teaching. Asian EFL Journal, 8(3),2.

Ellis, R. (2008). The Study of Second Language Acquistion. New York: Oxford University Press.

Esfandiari, Mehran. (2018). Task-based Learning Applied: Satisfactory Grammar Coverage. Defense Language Institute Foreign Language Center, Monterey, CA, 93944, The United States of America.

Ganta, T. G. (2015). The Strength and Weaknesses of Task-Based Learning (TBL) Approach. Scholarly Research Journal for Interdisciplinary Studies, Vol. 3 (16), 2760-2771.

Greenbaum, S., \& Nelson, G. (2002). An Introduction to English Grammar. Great Britain: Pearson Education Limited.

Hismanoglu, M. and Hismanoglu, S. (2011). Task-based Language Teaching: What Every EFL Teacher should do. Procedia Social and Behavioral Sciences, 15, 46-52.

Huang, Danyan. (2016). A Study on the Application of Task-based Language Teaching Method in a Comprehensive English Class in China. Journal of Language Teaching and Research. Vol. 7, No. 1, pp. 118-127.

Jeon, In-Jae \& Hahn, Jung-won. (2005). Exploring EFL Teachers' Perceptions of Task-Based Language Teaching: A case study of Korean secondary school or classroom practice. Mokpo National University, Korea. International Journal of English and Cultural Studies Vol. 1, No. 1 
Kafipour, Reza; Mahmoudi, Elaheh, \& Khojasteh, Laleh. (2018). The Effect OF Task-Based Language Teaching on Analytic Writing Classroom.

Kusmaryati, S. E. \& Amertaningrum, I. P. (2017). Exploring Students' Interest in Learning English: A Description Study in Elementary School in Kudus. English Education Department, 184-191.

Muawanah, Samrotul. (2014). The Relationship Between Students' Reading Habit and Their Reading Comprehension. Jakarta: Syarif Hidayatulloh State Islamic of University.

Nunan, D. (2004). Task-based language teaching. Cambridge, UK: Cambridge University Press.

Nurhayati, Dwi Astuti Wahyu, Djatmika, Riyadi Santosa, Tri Wiratno.(2018). Exploring Indonesian Interference on Morpho-Syntactic Properties. Javanese Speakers: A Case Study of English Lecturer and Students'Interaction in two Colloges in East Java, Indonesia. Pertanika Journal Social Science and Humanities (JSSH), Universiti Putra Malasyia Press, 26 (T): 257-282

Qosayere, I. (2015). The Effect of Grammar Correction on Students' Writing. International Interdisciplinary Journal of Education, Vol. 4 (1), 257-261.

Spradley, J. P. (2006). Metode Etnografi (Ethnographic Method) (M.Z. Elizabeth Trans). Yogyakarta: Tiara Wacana.

Sukmadinata, Nana Syaodih. (2003). Landasan Psikologi Proses Pendidikan. Bandung : Remaja Rosdakarya.

Thompson, Colin \& Millington, Neil. (2012). Task-Based Learning for Communication and Grammar Use. Language Education in Asia Journal. (3). 159-167. 10.5746/LEiA/12/V3/I2/A04/Thompson_Millington

Utaminingsih, M. N. (2013). Improving Students' Speaking Ability through Story Board Game. Journal of English Language Teaching, Vol. 2 (2), 1-7.

Willis, J. (1996). A framework for task-based learning. London: Longman.

Yildiz, Mustafa \& Senel, Mufidz. (2017). Teaching Grammar through Task-Based Language Teaching to Young EFL Learners. The Reading Matrix: An International Online Journal Volume 17, Number 2. 